\title{
Lesson study berbasis saintifik bagi guru pendidikan agama Kristen di Sekolah Dasar
}

\author{
Mercy Florence Halamury ${ }^{1}$, Christiana Demaja W. Sahertian ${ }^{2 *}$ \\ ${ }^{1,2}$ Institut Agama Kristen Negeri Ambon \\ *Correspondence: mayasahertian@gmail.com
}

\begin{tabular}{|c|c|}
\hline $\begin{array}{l}\text { https://orcid.org/0000- } \\
\text { 0003-1150-4143 } \\
\text { Keywords: } \\
\text { Christian education } \\
\text { teacher; } \\
\text { lesson study; } \\
\text { scientific; } \\
\text { guru PAK; } \\
\text { saintifik; } \\
\text { SD Inpres Yamalatu } \\
\text { Article History } \\
\text { Submitted: July } 07,2021 \\
\text { Revised: September } 09,2021 \\
\text { Accepted: October } 31,2021\end{array}$ & $\begin{array}{l}\text { Abstract: One of the coaching strategies that have been implemented to en- } \\
\text { courage changes in learning practices that have been occurring, leading to a } \\
\text { more effective direction is to carry out lesson study activities. Lesson studies } \\
\text { conducted for teachers at SD Inpres Yamalatu aim to train teachers to be more } \\
\text { professional in their competence, starting from planning lessons, determining } \\
\text { strategies and methods, media, and approaches that suit the learning needs of } \\
\text { students, so that students can develop all the potential that is in them. himself } \\
\text { critically, both cognitive, affective, and psychomotor. This research used Class- } \\
\text { room Action Research, with reference to the Hopkins model of classroom } \\
\text { action research. Data collection techniques, questionnaire observation, and } \\
\text { interviews. The results found in this study are lessons studies conducted at } \\
\text { Sekolah Dasar (SD) Inpres Yamalatu through the stages plan, do, see, can } \\
\text { improve the professionalism of Christian religious education teachers. }\end{array}$ \\
\hline $\begin{array}{l}\text { DOI: https://doi.org/ } \\
\text { 10.30995/kur.v7i2.324 } \\
\text { Copyright: } \bigcirc 2021 \text {, Authors. } \\
\text { License: } \\
\text { cc) }\end{array}$ & $\begin{array}{l}\text { Abstrak: Salah satu strategi pembinaan yang diterapkan guna mendorong } \\
\text { terjadinya perubahan dalam praktik pembelajaran yang selama ini terjadi, } \\
\text { menuju kearah yang lebih efektif adalah dengan melakukan kegiatan lesson } \\
\text { study. Lesson study yang dilakukan bagi guru di Sekolah Dasar (SD) Inpres } \\
\text { Yamalatu bertujuan untuk melatih guru agar semakin professional dalam } \\
\text { kompetensinya, mulai dari merencanakan pembelaran, menentukan strategi } \\
\text { dan metode, media dan pendekatan yang sesuai dengan kebutuhan belajar } \\
\text { siswa, sehingga siswa dapat mengembangkan seluruh potensi yang ada di } \\
\text { dalam dirinya secara kritis, baik secara kognitif, afektif dan psikomotorik. Jenis } \\
\text { penelitian yang digunakan adalah penelitian Tindakan Kelas, dengan mengacu } \\
\text { pada penelitian tindakan kelas model Hopkins. Teknik pengumpulan data, } \\
\text { observasi angket, dan wawancara. Hasil yang ditemui dalam penelitian ini } \\
\text { adalah lesson study yang dilakukan di Sekolah Dasar (SD) Inpres Yamalatu } \\
\text { melalui tahapan plan, do, see, dapat meningkatkan professionalism Guru PAK. }\end{array}$ \\
\hline
\end{tabular}

\section{Pendahuluan}

Akhir-akhir ini, Isu mengenai rendahnya kualitas pendidikan banyak menyebabkan perdebatan antar berbagai kalangan. Para guru yang berhubungan langsung dengan para siswa seringkali dianggap sebagai salah satu penyebab rendahnya kualitas pendidikan tersebut, meskipun tidak bisa dipungkiri bahwa sebenarnya banyak hal yang berpengaruh terhadap kualitas pendidikan, mulai dari kurikulum, fasilitas di sekolah, guru, kepala sekolah, orang tua, dan lembaga terkait lainnya. Das Saliriwati menyatakan bahwa saat ini Indonesia sedang melakukan pembenahan diberbagai bidang termasuk bidang pendidikan yang merupakan bidang penentu bagi majunya 
suatu negara. ${ }^{1}$ Salah satu pembenahan yang menjadi fokus utama adalah pembenahan terhadap kompetensi guru. Guru sebagai ujung tombak pelaksanaan pendidikan di semua jenjang dan satuan pendidikan memegang peranan penting dalam mendukung terciptanya sumber daya manusia yang berkualitas.

Guru merupakan komponen yang sangat menentukan keberhasilan suatu pendidikan karena guru merupakan figur sentral dalam pembelajaran. Meskipun paradigma baru menggeser teacher centred menjadi student center, bukan berarti bahwa peran dan tugas guru dalam membelajarkan peserta didik berkurang. Guru tetap menentukan keberhasilan peserta didik, terutama terkait dengan proses pembelajaran karena kreativitas guru sangat di perlukan untuk mentransfer ilmu pengetahuan dan menggali potensi peserta didik. Untuk mengamati kompetensi guru dalam hal pengembangan potensi peseta didik, Dirjen pendidikan Mutu Pendidikan dan Tenaga Kependidikan telah menetapkan salah satu tujuan indikatornya, yaitu guru merancang dan melaksanakan aktivitas pembelajaran untuk memunculkan daya kreativitas dan kemampuan berpikir kritis siswa. ${ }^{2}$ Dalam hubungan dengan itulah maka Anis Baswedan, dalam Munif Chatib mengatakan bahwa, hal penting yang harus dilakukan guru adalah selalu belajar untuk meningkatkan kualitas dirinya. ${ }^{3}$ Guru yang berkualitas dicirikan dengan keinginan untuk selalu menambah pengetahuannya dari buku, internet, ataupun sharing dengan rekan seprofesi melalui kegiatan ilmiah seperti seminar, workshop, dan pelatihan.

Dengan melihat berbagai anjuran yang diamanatkan Kurikulum 2013 guna mencapai orientasi akhir agar peserta didik memiliki kemampuan kreatif, kritis, komunikatif, sekaligus berkarakter, maka pemberlakuan kurikulum 2013 menuntut sejumlah perubahan mendasar pada proses pembelajaran yang berlangsung di persekolahan. Darling-Hammond dalam Yunus Abidin $^{4}$, menyatakan bahwa guru hendaknya mampu untuk mempersiapkan seluruh siswa agar memiliki kemampuan berpikir yang meliputi kemampuan menemukan masalah, menemukan, mengintegrasikan dan menyintesis informasi, mencipta solusi baru dan menciptakan kemampuan siswa dalam hal belajar madiri dan bekerja dalam kelompok, yang merupakan substansi dari kurikulum 2013 itu sendiri. Pendekatan saintifik menurut Daryanto adalah proses pembelajaran yang di rancang sedemikian rupa agar peserta didik secara aktif mengkonstruksi konsep, hukum atau prinsip melalui tahap-tahapan mengamati (untuk mengidentifikasi atau menemukan masalah), merumuskan masalah, mengajukan atau merumuskan hipotesis, mengumpulkan data dengan berbagai teknik, menganalisis data, menarik kesimpulan, dan mengomunikasikan konsep, hukum atau prinsip yang di temukan. ${ }^{5}$ Pendekatan saintifik ini dimaksudkan untuk memberikan pemahaman kepada peserta didik dalam mengenal, memahami berbagai materi menggunakan pendekatan ilmiah, bahwa informasi bisa berasal dari mana saja, kapan saja, tidak bergantung pada informasi searah dari guru.

Menurut Yunus Abidin pendekatan scientific dapat membina kemampuan siswa memecahkan masalah melalui serangkaian aktivitas inkuiri yang menuntut kemampuan berpikir kritis, kreatif, dan berkomunikasi dalam upaya meningkatkan pemahaman siswa. ${ }^{6}$ Searah dengan pendapat di atas, Carin dan Sund dalam Ahmad Yani, menyatakan bahwa begitu pentingnya pembelajaran dengan pendekatan saintifik sehingga mendapat rekomendasi dari UNESCO terkait dengan konsep "the four pillars of education", yaitu belajar untuk mengetahui (learning to know), belajar melakukan segala sesuatu, learning to do belajar hidup bersama sebagai dasar untuk berpartisipasi dan bekerja sama dengan orang lain dalam keseluruhan aktivitas kehidupan manu-

\footnotetext{
${ }^{1}$ Das Salirawati, Smart Teaching: Solusi Menjadi Guru Profesionl (Jakarta: Bumi Aksara, 2018)

${ }^{2}$ Dirjen Peningkatan Mutu Pendidik dan Tenaga Kependidikan, Pedoman Pelaksanaan Kinerja Guru (Jakarta: Kementerian Pendidikan dan Kebudayaan, 2012).

${ }^{3}$ Munif Chatib, Gurunya Manusia: Menjadikan Semua Anak Istimewa dan Semua Anak Juara (Bandung: Kaifa, 2012)

${ }^{4}$ Yunus Abidin, Desain Sistem Pembelajaran Dalam Konteks Kurikulum 2013 (Bandung: PT Refika Aditama, 2014)

${ }^{5}$ Daryanto, Pendekatan Pembelajaran Saintifik Kurikulum 2013 (Yogyakarta: Penerbit Gava Media, 2014).

${ }^{6}$ Ibid., 23
} 
sia (learning to live to gether), dan belajar menjadi dirinya (learning to be). ${ }^{7}$ Dari empat pilar di atas, pembelajaran dengan pendekatan saintifik yang banyak menggunakan strategi "guided discovery" sangat membantu peserta didik untuk bagaimana cara belajar (learning to learn) atau membantu siswa memperoleh pengetahuan dengan cara menemukannnya sendiri. Dengan demikian adalah tidak tepat jika pembelajaran yang dilakukan oleh seorang guru mengabaikan kemampuan kritis dan kreatifitas siswa dalam bernalar dan berkomunikasi terhadap apa yang mereka peroleh atau diketahui setelah menerima materi pembelajaran.

Realitas yang sampai saat ini dijumpai sebagai gejala umum dari ketidakefektifan pelaksanaan pembelajaran berbasis saintifik di sekolah-sekolah pada umumnya adalah kurangnya pemahaman guru tentang substansi kurikulum 2013 yang berbasis saintifik, selain faktor kemalasan guru dan ketidakkreativan guru untuk mengembangkan diri sesuai tuntutan kurikulum 2013 yang disebabkan terbiasanya guru dengan kurikulum sebelumnya. Khususnya pada sekolah-sekolah yang ada pada daerah terpencil, fenomena yang sama di temui pada salah satu sekolah di Kecamatan Telutih, Kabupaten Maluku Tengah yaitu Sekolah Dasar Inpres Yamalatu.

SD Inpres Yamalatu dengan jumlah guru 7 orang (4 orang PNS + 3 orang honorer), mengalami masalah dalam penerapan pembelajaran berbasis saintifik, selain dari kurangnya pemahaman guru, tetapi juga keterbatasan informasi dalam bentuk pelatihan atau sosialisasi kurikulum 2013. Dalam survei yang dilakukan peneliti ternyata masalah terkait implementasi kurikulum 2013 pada SD inpres Yamalatu menjadi sangat kompleks. Guru masih mengalami kesulitan dalam memahami serta mempersiaapkan seluruh dokumen terkait kurikulum 2013. Konsep kurikulum 2013 dengan pendekatan saintifik pun merupakan hal baru bagi para guru di SD Inpres Yamalatu. Khusus Bagi mata pelajaran PAK, pelaksanaan pembelajaran dengan pendekatan Kurikulum 2013, sama sekali belum pernah dilakukan. Dalam realitasnya, keterbatasan pemahaman guru PAK terhadap substansi kurikulum 2013 dan penerapannya dengan pendekatan saintifik, sangat berdampak pada proses pembelajaran.

Depdiknas, Depag dan JICA (2009) mendefinisikan lesson study sebagai model pembinaan profesi guru dengan menerapkan tiga prinsip pembelajaran, yakni perencanaan (plan), pelaksanaan (do), refleksi (see). ${ }^{8}$ Shelley Friedkin (2005) mendefinisikan lesson study sebagai suatu proses yang melibatkan guru yang bekerja sama untuk merencanakan, mengobservasi, menganalisis, dan memperbaiki pembelajarannya. Dengan kerja sama beberapa orang guru mata pelajaran, maka pembelajaran bisa langsung dievaluasi setelah dilaksanakan di kelas. Hasil evaluasi diarahkan untuk langkah perbaikan dalam pembelajaran. Lesson Study (LS), pada hakikatnya, merupakan aktivitas klasikal berkesinambungan yang memiliki implikasi praktis dalam pendidikan. Bill Cerbin dan Bryan Kopp, mengemukakan bahwa Lesson Study memiliki 4 (empat) tujuan utama ${ }^{9}$, yaitu untuk: memperoleh pemahaman yang lebih baik tentang bagaimana siswa belajar dan guru mengajar; memperoleh hasil-hasil tertentu yang dapat dimanfaatkan oleh para guru lainnya, di luar peserta lesson study; meningkatkan pembelajaran secara sistematis melalui inkuiri kolaboratif; membangun sebuah pengetahuan pedagogis, dimana seorang guru dapat menimba pengetahuan dari guru lainnya. Menyikapi persoalan yang terjadi dalam proses pembelajaran PAK sekaligus menyempurnakan kualitas guru di SD Inpres Yamalatu maka dilakukanlah lesson study berbasis scientific yang di dalamnya melibatkan guru PAK dan guru kelas di SD Inpres Yamalatu.

\section{Metode Penelitian}

Jenis penelitian yang digunakan adalah Penelitian Tindakan Kelas (Classroom Action Research), dengan mengacu pada penelitian tindakan kelas model Hopkins. Sanjaya, menyatakan Hopkins menggambarkan proses pelaksanaan PTK mengikuti bentuk spiral yang meliputi tahapan mengi-

\footnotetext{
${ }^{7}$ Ahmad Yani, Mindset Kurikulum 2013. Bandung: Alfabeta

${ }^{8}$ Depdiknas, Depag dan JICA. Panduan untuk Lesson Study Berbasis MGMP dan Lesson Study Berbasis Sekolah (Jakarta: Program Peningkatan Kualitas (PELITA SMP/MTs), 2009)

${ }^{9}$ Bill Cerbin \& Briyan Kopp. A Brief Introduction to College Lesson Study: Lesson study Project (online. http://www.uwlax.edu/soft/Isp/Index2.htm; 2009
} 
dentifikasi adanya permasalahan dalam proses kegiatan belajar, perencanaan tindakan, pelaksanaan tindakan, observasi, refleksi, kemudian melakukan perencanaan ulang. ${ }^{10}$ Tindakan yang dilakukan terdiri dari dua siklus di mana lesson study juga terdiri dari dua siklus. Dengan 2 siklus Penelitian Tindakan Kelas (Action Research) maka dilakukan lesson study, yang diterapkan dengan tahapan: Plan, Do, See. Penelitian ini dirancang untuk dilaksanakan bersiklus, adapun setiap siklus meliputi Perencanaan (Plan), Pelaksanaan (Do), Refleksi (See). Metode Pengumpulan data; Observasi terhadap guru model dalam pembelajaran, Angket dan wawancara. Pelaksanaan penelitian dimulai dari Agustus-September 2019 di SD Inpres Yamalatu, Kecamamatan Telutih, Kabupaten Maluku Tengah. Subjek dalam penelitian ini adalah guru kelas yang adalah guru PAK sebanyak empat orang. Instrumen yang digunakan dalam penelitian ini adalah lembar observasi dan angket. Metode analisis data menggunakan pendekatan proses sikslis yakni data analisis sejak tindakan pembelajaran dilaksanakan (sejak dari plan, do, see) dikembangkan selama proses pembelajaran berlangsung sampai diperoleh pembelajaran yang berkualitas.

\section{Hasil dan Pembahasan}

Urgensi/keutamaan penelitian ini tidak hanya melihat proses pelaksanaan lesson study sebagai keutamaan untuk memberi makna terhadap proses pembelajaran dengan pendekatan scientific namun focus utamanya adalah kegiatan lesson study ini melatih guru untuk semakin professional dalam kompetensinya, mulai dari merencanakan pembelaran, menentukan strategi dan metode, media dan pendekatan yang sesuai dengan kebutuhan belajar siswa, sehingga siswa dapat mengembangkan seluruh potensi yang ada di dalam dirinya secara kritis, baik secara kognitif, afektif dan psikomotorik.

Dalam proses penelitian ini sesuai hasil analisis kebutuhan, maka kegiatan pertama yang dilakukan peneliti adalah memberikan pemahaman kepada guru, khusus guru PAK di SD Inpres Yamalatu tentang Kurikulum 2013 sebelum kegiatan lesson study dilakukan. Peneliti merencanakan satu hari khusus sebagai agenda pelatihan kurikulum 2013 bagi para guru yaitu pengenalan tentang substansi kurikulum 2013 dan bagaimana implementasi kurikulum 2013 dalam pembelajaran PAK. Kegiatan sosialisasi bukan saja dihadiri oleh guru PAK tetapi oleh semua guru mata pelajaran umum pada SD Inpres Yamalatu. Hasil wawancara dengan beberapa orang guru, kegiatan ini mendapat respon yang cukup baik, karena selama ini belum pernah dilakukan sosialisasi K13 berbasis sekolah, sehingga semua guru tidak bias dilibatkan. Setelah semua guru telah memahami substansi dari K13, maka peneliti melanjutkan dengan pelaksanaan kegiatan Lesson study. Pelaksanaan Lesson Study mata pelajaran PAK Di Kelas 1 SD Inpres Yamalatu dilaksanakan dalam 3 tahap yaitu: (1) Perencanaan (Plan) meliputi kegiatan penyusunan RPP, pembuatan media dan pembuatan lembar observasi; (2) Pelaksanaan (Do) dalam kegiatan pembelajaran di kelas; dan (3) Refleksi (See) untuk memaparkan hasil pengamatan dan temuan penelitian, dengan proses sebagai berikut:

\section{Siklus I}

Tahap Plan dilaksanakan pada hari Selasa tanggal 13-14 Agustus 2019 pada pukul 10.00-10.30 dilaksanakan di ruang guru SD Inpres Yamalatu dan di Rumah salah seorang guru saat di luar jam sekolah. Tahap plan dilakukan bersama guru model dan juga peneliti. Pada tahap ini guru model dan juga peneliti melakukan tahap-tahap yaitu menyusun RPP dan membuat rancangan medi pembelajaran yang diperluan untuk pembelajaran dikelas.

Tahap Do, Kegiatan awal pelajaran PAK dengan pendekatan LSBS dialukan pada hari Rabu 15-16 Agustus 2019 pada pukul 10.00-10.30. di SD Inpres Yamalatu Kelas 1. Tahap See dilaksa-

\footnotetext{
${ }^{10}$ Wina Sanjaya, Strategi Pembelajaran Berorientasi Standar Proses Pendidikan (Jakarta: Kencana Prenada Media Group, 2010).
} 
nakan pada hari Kamis, 17-18 Agustus 2019 observer yang ditentukan adalah ibu Welly Taluku dan Ibu Rina Sifata. Yang dilanjutkan dengan refleksi oleh observer.

Selanjutnya Lesson Study Berbasis Saintifik yang dilakukan di SD Inpres Yamalatu dari tahapan Plan, Do, See, adalah sebagai berikut: Proses penyusunan Rencana pembelajaran yang dilakukan oleh guru PAK berlangsung di sekolah dalam diskusi tetapi juga di rumah, RPP itu selanjutnya didiskusikan lagi. Pada awal pembuatan RPP berbasis saintifik guru sangat merasa kesulitan karena harus mengintegrasikan pendekatan saintifik dalam setiap proses, apalagi selama ini guru PAK hanya terbiasa dengan mengambil langsung materi dari buku tanpa melakukan berbagai pengembangan isi serta relefansinya dengan konteks. Oleh karena itu, lewat berbagai diskusi, dan workshop yang dilakukan peneliti mengawali proses penelitian ini, juga lewat berbagai bimbingan, guru PAK dapat melakukan proses pembelajaran dengan menggunakan RPP K13 berbasis saintifik, walaupun dalam pelaksanaan pembelajaran belum secara maksimal tampilan guru di kelas, (masih menghafal setiap tahapan)dan melakukannya dengan hati-hati karena takut melakukan kesalahan, namun proses pembelajaran PAK dikelas 1 SD Inpres Yamalatu dapat dikendalikan oleh guru model.

\section{Siklus II}

Pada siklus II, guru model, dalam hal ini guru Pendidikan Agama Kristen menyampaikan rencana pembelajaran yang dibuat berdasarkan hasil koreksi dan perbaikan kekurangan pada Siklus I oleh observer. Selanjutnya kegitan pembelajaran (do) dilaksanakan pada 26,27,28 Agustus 2019. Selanjutnya, pada tanggal 29 Oktober 2019 dilanjutkan dengan Refleksi terhadap seluruh proses pembbelajaran yang sudah dilaksanakan pada siklus II. Apa bila masih ada kelemahan maka akan dijadikan acuan untuk melakukan perbaikan, untuk digunakan sebagai pedoman bagi pembelajaran selanjutnya.

Tabel 1: Hasil Refleksi PTK Siklus I

\begin{tabular}{|l|l|l|l|l|l|}
\hline No & Indikator & GM & GM & GM & GM \\
\hline 1 & Kelengkapan RPP & 3 & 3 & 3 & 4 \\
\hline 2 & Kemampuan Membuka Pelajaran & 3 & 3 & 4 & 3 \\
\hline 3 & Kejelasan penyampaian materi dengan terintegrasi 5M & 3 & 3 & 4 & 3 \\
\hline 4 & Pengelolaan Kelas & 3 & 3 & 3 & 3 \\
\hline 5 & Pengorganisasian siswa & 4 & 3 & 3 & 3 \\
\hline 6 & Evaluasi Proses Pembelajaran & 3 & 3 & 4 & 4 \\
\hline 7 & Ulasan Kesimpulan & 3 & 4 & 4 & 3 \\
\hline 8 & Reward and Punishment & 3 & 3 & 4 & 3 \\
\hline 9 & Pemberian Tugas & 4 & 4 & 3 & 3 \\
\hline 10 & Kemampuan menutup Pelajaran & 3 & 3 & 4 & 4 \\
\hline
\end{tabular}

Tabel 2: Hasil Refleksi PTK Pada Siklus II

\begin{tabular}{|l|l|l|l|l|l|}
\hline No & Indikator & GM & GM & GM & GM \\
\hline 1 & Kelengkapan RPP & 4 & 4 & 4 & 4 \\
\hline 2 & Kemampuan Membuka Pelajaran & 4 & 4 & 4 & 5 \\
\hline 3 & Kejelasan memberikan materi dengan terintegrasi 5M & 4 & 4 & 4 & 4 \\
\hline 4 & Pengelolaan Kelas & 4 & 4 & 4 & 4 \\
\hline 5 & Pengorganisasian siswa & 4 & 4 & 4 & 4 \\
\hline 6 & Evaluasi Proses Pembelajaran & 4 & 5 & 4 & 4 \\
\hline 7 & Ulasan dan Kesimpulan & 4 & 4 & 4 & 5 \\
\hline 8 & Reward and Punishment & 4 & 4 & 4 & 4 \\
\hline 9 & Pemberian Tugas & 4 & 5 & 5 & 4 \\
\hline 10 & Kemampuan menutup Pelajaran & 4 & 4 & 5 & 4 \\
\hline
\end{tabular}

Keterangan: $\mathrm{GM}=$ Guru Model

5 = Sangat baik; 4 = Baik; 3 = Cukup; 2 = Sangat Kurang; 1 = Kurang 
Hasil Penelitian pada Siklus I dan Siklus II terdapat peningkatan guru PAK dalam proses pembelajaran dengan menggunakan Perangkat K13. Perkembangan ini menunjukan bahwa proses lesson study pada tahap do oleh guru menunjukan kemajuan yang signifikan.

Keberhasilan ini dapat dirasakan karena guru PAK di SD Inpres Yamalatu telah menyadari bahwa untuk melakukan suatu kegiatan pembelajaran, Kurikulum menjadi panduan yang harus disiapkan oleh seorang guru. Dalam hal ini rencana pelaksanaan pembelajaran (RPP) sebagai rancangan kegiatan guru yang berisi skenario pembelajaran tahap demi tahap mengenai hal-hal yang akan dilakukakan guru bersama siswa terkait topik atau pokok bahasan yang akan dipelajari demi mencapai kompetensi standar yang telah ditentukan. Berdasarkan hasil wawancara dengan kepala sekolah SD Inpres Yamalatu, dikatakan bahwa Rencana pembelajaran jangan diartikan sebagai laporan atau beban guru yang harus disusun dan dilaporkan kepada kepala sekolah atau untuk kepentingan supervisi, tapi harus dilihat sebagai rencana guru yang memuat persiapan dan langkah pembelajaran yang akan dilaksanakan di kelas.

Berdasarkan rencana pembelajaran yang telah disusun guru model pada siklus I dan mengalami penyempurnaan pada siklus II guru PAK yang selama ini mengajar pada kelas 1 SD Inpres Yamalatu melaksanakan pembelajaran di kelas yang telah ditentukan dan guru yang lain bertindak sebagai observer untuk mengamati proses pembelajaran dengan menggunakan instrumen penelitian yang telah dikembangkan. Bersamaan dengan dilaksanakannya proses pembelajaran, dilakukan pengambilan data yang diperlukan untuk kepentingan refleksi. Hal-hal yang mendapat fokus perhatian ketika observer mengobservasi, adalah kelengkapan RPP, pengelolaan kelas, aktivitas siswa, dan ketercapaian tujuan untuk setiap tahap kegiatan pembelajaran.

Berdasarkan hasil pengamatan observer dan refleksi yang disampaikan, dinyatakan bahwa tahap lesson study yang dilakukan pada siklus I dan siklus II merupakan cara yang efektif untuk meningkatkan kualitas pembelajaran yang dilakukan guru kepada siswa. Selain itu apabila lesson study dirancang dengan sebaik-baiknya maka ini merupakan kegiatan yang akan menjadikan guru PAK yang professional dan Inovatif. Guru PAK harus merangsang kemampuan siswa akar tidak sekedar mengalami pembelajaran saja, tetapi kegiatan pembelajaran yang mereka alami benar-benar meninggalkan kesan tersendiri dan memberi makna yang berarti. Oleh karena itu Guru PAK tidak boleh menyerah dengan keadaan. Melalui LS, guru PAK dapat mengkaji dan mengembangkan pembelajaran yang terbaik, misalnya guru mampu menghasilkan RPP yang baik, Media yang cocok dan produk lain yang berkaitan dengan pengembangan pembelajaran PAK.

Lesson Study memungkinkan guru PAK memperdalam pengetahuan mengenai materi pokok yang diajarkan. Dengan melaksanakan lesson study, guru PAK dapat mengidentifikasi dan mengorganisasi informasi apa yang mereka perlukan untuk memecahkan masalah pembelajaran yang menjadi fokus kajian dalam lesson study. Melalui lesson study guru secara bersama-sama berkesempatan untuk memikirkan pengetahuan yang dianggap penting, apa saja yang belum mereka ketahui mengenai hal itu, dan berusaha mencari informasi yang mereka perlukan untuk membelajarkan siswa. Lesson study memberi kesempatan kepada guru secara kolaboratif merancang pembelajaran. Aktivitas kolaboratif dapat memberikan kesempatan kepada guru untuk memikirkan pembelajarannya sendiri setelah mempertimbangkannya dengan pengalaman yang dilakukan oleh guru yang lain. Melalui lesson study guru PAK dapat saling membelajarkan melalui aktivitas-aktivitas shared knowledge.

Lesson study memberi kesempatan kepada guru PAK untuk mengkaji secara cermat cara dan proses belajar serta aktivitas siswa. Fokus lesson study yang dilakukan di SD Inpres Yamalatu selain untuk meningkatkan profesionalisme guru PAK juga diarahkan pada peningkatan pembelajaran melalui pengamatan terhadap aktivitas belajar siswa. Pengamatan tersebut bertujuan untuk menemukan cara-cara untuk meningkatkan kegiatan belajar dan kegiatan berpikir siswa. Oleh sebab itu, aktivitas lesson study sesungguhnya bukan menyalahkan guru atau mengritik kesalahan guru. Di dalam lesson study, guru perlu mengetahui bahwa siswa memang belajar, termotivasi, dan berkembang.

Leson study di SD Inpres Yamalatu memberi kesempatan kepada guru PAK melihat hasil pembelajarannya sendiri melalui respon siswa dan tangapan para guru yang lain. Data yang 
diberikan oleh pengamat dan guru yan lain menjadi masukan bagi guru yang melaksanakan lesson study. Oleh karena Lesson Study dapat meningkatkan profesionalisme guru, maka pelaksanaan lesson study secara berkesinambungan diyakini dapat meningkatkan praktik-praktik pembelajaran sehari-hari. Peningkatan praktik-praktik pembelajaran akan bermuara pada peningkatan kualitas proses dan produk belajar siswa.

\section{KESIMPULAN}

Lesson study yang dilakukan, memberikan banyak manfaat bagi guru PAK di SD Inpres Yamalatu, antara lain: Guru PAK dapat mengetahui kinerjanya dalam pembelajaran; guru PAK dapat memperoleh umpan sumbang saran dari guru lain; guru PAK dapat melakukan koreksi terhadap dirinya dengan menghadirkan perubahan-perubahan terkait dengan tuntutan kurikulum dan kebutuhan peserta didik. Lesson study memberi kesempatan kepada guru PAK secara kolaboratif merancang pembelajaran. Aktivitas kolaboratif yang dilakukan memberikan kesempatan kepada guru PAK untuk memikirkan pembelajarannya sendiri setelah mempertimbangkannya dengan pengalaman yang dilakukan oleh guru yang lain. Melalui lesson study guru dapat saling membelajarkan melalui aktivitas-aktivitas shared knowledge. Lesson study memberi kesempatan kepada guru untuk mengkaji secara cermat cara dan proses belajar serta aktivitas siswa.

\section{REFERENSI}

Abidin, Yunus. Desain Sistem Pembelajaran Dalam Konteks Kurikulum 2013, Bandung: PT Refika Aditama, 2014.

Abidin, Yunus. Desain Sistem Pembelajaran Dalam Konteks Kurikulum 2013, Bandung: PT Refika Aditama, 2016.

Bill Cerbin \& Briyan Kopp. A Brief Introduction to College Lesson Study. Lesson study Project (online. http://www.uwlax.edu/soft/Isp/Index2.htm, 2009

Chatib, Munif. Gurunya Manusia : Menjadikan Semua Anak Istimewa dan Semua Anak Juara, Bandung: Kaifa, 2012.

Depdiknas, Depag dan JICA. Panduan untuk Lesson Study Berbasis MGMP dan Lesson Study Berbasis Sekolah. Jakarta: Program Peningkatan Kualitas (PELITA SMP/MTs), 2009.

Dirjen Peningkatan Mutu Pendidik dan Tenaga Kependidikan. Pedoman Pelaksanaan Kinerja Guru (PK Guru)., Jakarta: Kementerian Pendidikan dan Kebudayaan, 2012

Salirawati, Das. Smart Teaching: Solusi Menjadi Guru Profesionl, Jakarta : Bumi Aksara, 2018 Sanjaya, Wina. Strategi Pembelajaran Berorientasi Standar Proses Pendidikan, Jakarta : Kencana Prenada Media Group, 2010

Shelley Friedkin. What is Lesson Study? 2005http://www.lessonresearch.net/

Yani, Ahmad. Mindset Kurikulum 2013, Bandung: Alfabeta, 2014 